\title{
Effects of cAMP and cGMP on L-Type Calcium Channel Currents in Rat Mesenteric Artery Cells
}

\author{
Kyoji Taguchi, Masaki Ueda and Takao Kubo \\ Department of Pharmacology, Showa College of Pharmaceutical Sciences, Machida, Tokyo 194, Japan \\ Received October 17, $1996 \quad$ Accepted March 18, 1997
}

\begin{abstract}
L-type $\mathrm{Ca}^{2+}$ channel currents in cultured rat mesenteric artery smooth muscle cells were recorded by the cell-attached patch-clamp technique. Depolarizing voltage steps from a holding potential of $-40 \mathrm{mV}$ elicited voltage-dependent inward $\mathrm{Ba}^{2+}$ currents. The inward currents were inhibited by nifedipine $(10 \mu \mathrm{M})$ but enhanced by Bay K $8644(5 \mu \mathrm{M})$, which suggests that the inward currents are carried almost exclusively by L-type $\mathrm{Ca}^{2+}$ channels. Application of dibutyryl cAMP $(0.1-1 \mu \mathrm{M})$ and forskolin $(0.01-1$ $\mu \mathrm{M}$ ) enhanced the activity of these $\mathrm{Ca}^{2+}$ channels. The dibutyryl cAMP induced enhancement of $\mathrm{Ca}^{2+}$ channels was antagonized by the serine/threonine kinase inhibitor H-8 $(1 \mu \mathrm{M})$. Application of 8-bromocGMP $(0.01-1 \mu \mathrm{M})$ and the cGMP inducer nitroglycerin $(0.01-1 \mu \mathrm{M})$ inhibited the activity of these $\mathrm{Ca}^{2+}$ channels, and the inhibition of channel activity induced by 8-bromo-cGMP was antagonized by the serine/threonine kinase inhibitor H-8 $(1 \mu \mathrm{M})$. These results suggest that in rat mesenteric artery cells, the $\mathrm{L}$-type $\mathrm{Ca}^{2+}$ channel current is enhanced by a rise in intracellular cAMP levels and suppressed by a rise in intracellular cGMP levels. Furthermore, cGMP-induced $\mathrm{Ca}^{2+}$ channel inhibition may play a role in the expression of the nitric oxide-mediated vasodilating action of drugs such as nitroglycerin and atrial natriuretic peptide.
\end{abstract}

Keywords: $\mathrm{Ca}^{2+}$ channel, cAMP, cGMP, Mesenteric artery, Patch-clamp

Voltage-dependent $\mathrm{Ca}^{2+}$ channels are essential for vascular smooth muscle contraction (1) and consist of 2 types, the L-type and T-type (2). L-type $\mathrm{Ca}^{2+}$ channels are important as the sites of action of the $\mathrm{Ca}^{2+}$ antagonists such as 1,4-dihidropyridines, verapamil and diltiazem, which are the drugs of choice for the treatment of cardiovascular diseases $(3,4)$.

In cardiac muscle cells, the L-type $\mathrm{Ca}^{2+}$ channel is well-known to be enhanced via a phosphorylation process induced by a cAMP-dependent kinase (protein kinase A) $(5,6)$. Although cAMP is also an important second messenger in vascular smooth muscle cells $(7,8)$, there is still considerable controversy concerning regulation of $\mathrm{Ca}^{2+}$ channels via cAMP in vascular smooth muscle cells. A rise in intracellular cAMP levels is reported to enhance L-type $\mathrm{Ca}^{2+}$ channels in porcine coronary artery cells (9) and rabbit portal vein cells (10). In contrast, dibutyryl cAMP has been shown to inhibit the L-type $\mathrm{Ca}^{2+}$ channel current in rabbit aorta (11). Isoprenaline has also been shown to suppress the L-type $\mathrm{Ca}^{2+}$ channel inward current in rabbit ear artery cells (12).

cGMP is another important second messenger in vas- cular smooth muscle cells $(13,14)$. Vasodilating substances like acetylcholine and histamine release nitric oxide from vascular endothelium; this results in the nitric oxide entering vascular smooth muscle cells to produce activation of guanylate cyclase, which in turn produces cGMP, leading to vascular relaxation $(15,16)$. Nitrate vasodilators like nitroglycerin also release nitric oxide to mediate their blood vessel relaxing effects (17). However, little is known of $\mathrm{Ca}^{2+}$ channel regulation by cGMP in vascular smooth muscle cells. In the present study, the effects of membrane permeable cAMP and cGMP analogues and drugs that induce both cyclic nucleotides on the L-type $\mathrm{Ca}^{2+}$ channel were examined in rat mesenteric smooth muscle cells using the cell-attached patch technique.

\section{MATERIALS AND METHODS}

\section{Preparation}

Smooth muscle cells of the mesenteric artery of male Wistar rats $(80-120 \mathrm{~g})$ were obtained as previously described (18). Briefly, mesenteric arteries were excised 
and cut into small pieces in normal Tyrode's solution following removal of the endothelial tissue. The pieces were then explanted in cultured dishes filled with medium 199 containing $10 \%$ fetal bovine serum, $100 \mu \mathrm{g} / \mathrm{ml}$ of streptomycin and $100 \mu \mathrm{g} / \mathrm{ml}$ of penicillin and stored in a $\mathrm{CO}_{2}$ incubator $\left(5 \% \mathrm{CO}_{2}, 37^{\circ} \mathrm{C}\right)$. Three or four glass coverslips were placed on the bottom of each culture dish. Single smooth muscle cells that migrated out of the tissues and adhered to the coverslips during primary culture for 6-10 days were used for the experiments. No proteolytic enzyme was used for isolation of single cells.

B

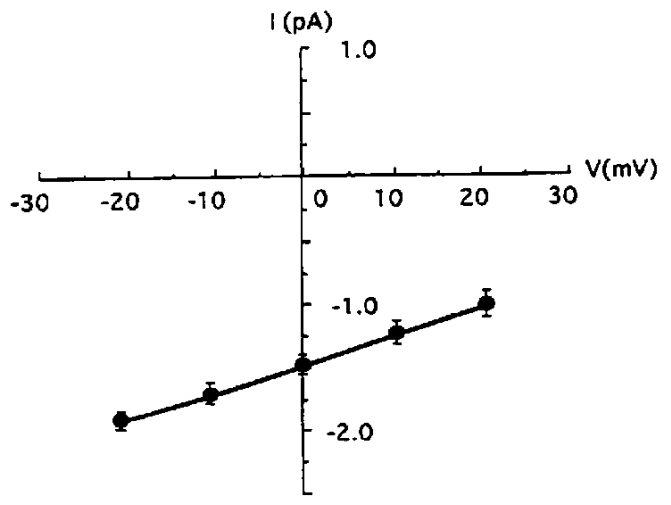

$+10 \mathrm{mv}-\mathrm{THrr}$

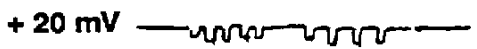

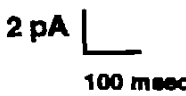

Fig. 1. Inward currents elicited by voltage step depolarizations from a holding potential of $-40 \mathrm{mV}$. Depolarizing pulses of $400 \mathrm{msec}$ in duration to various membrane potentials were applied. A: Typical tracings of the currents are shown. B: The current-voltage relationship of the peak current (mean \pm S.E., $n=6$ ).
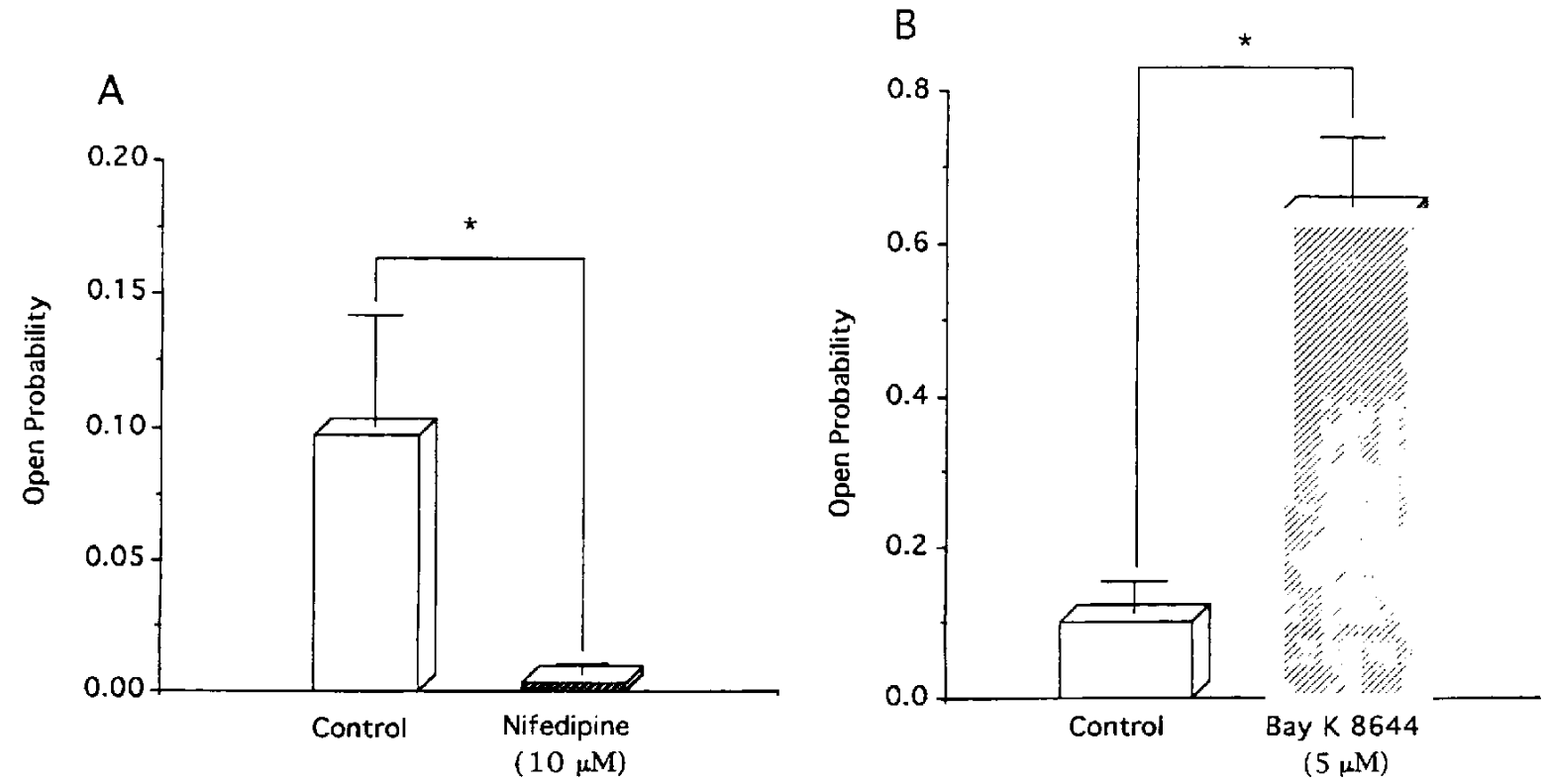

Fig. 2. Effects of nifedipine $(10 \mu \mathrm{M})$ and Bay $\mathrm{K} 8644(5 \mu \mathrm{M})$ on open probability of inward currents elicited by a voltage step to $+20 \mathrm{mV}$ from a holding potential of $-40 \mathrm{mV}$. Values are each the mean \pm S.E. from 5 experiments. ${ }^{*} \mathrm{P}<0.05$, compared to the control. 
A

a. Contral
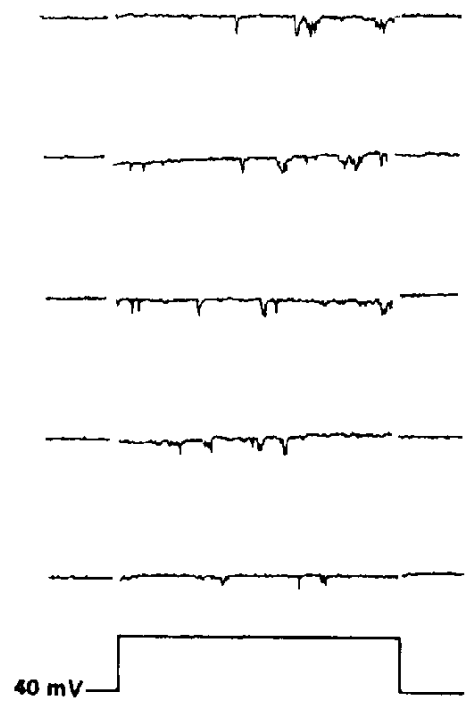

B

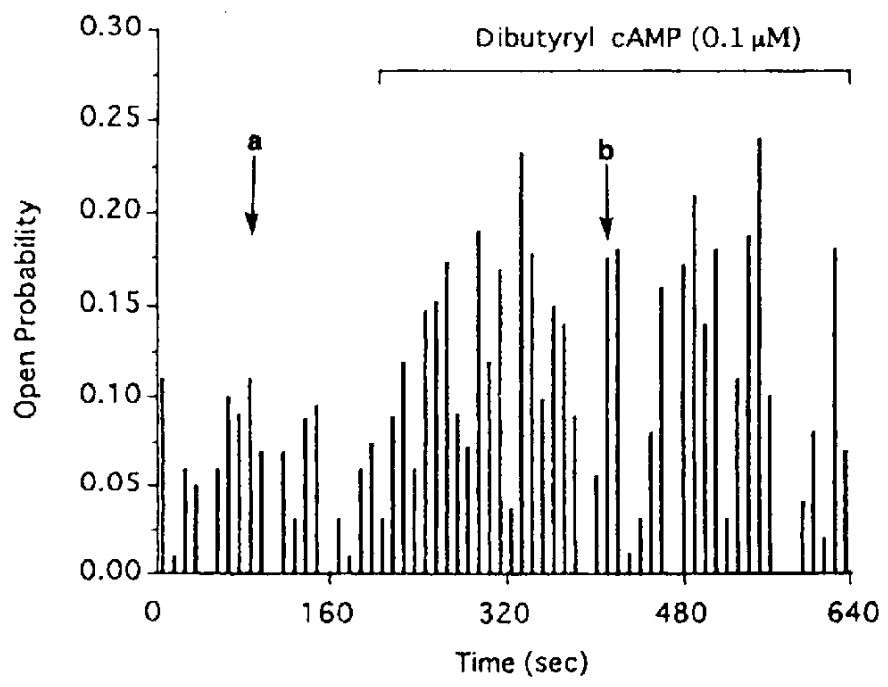

\section{b. Dibutyryl cAMP}
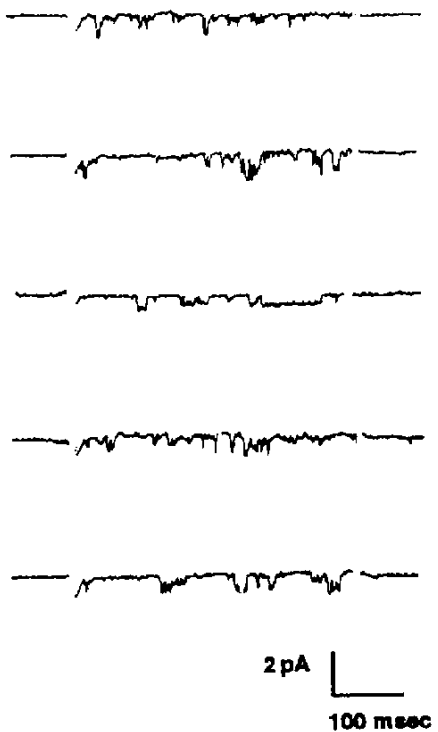

C

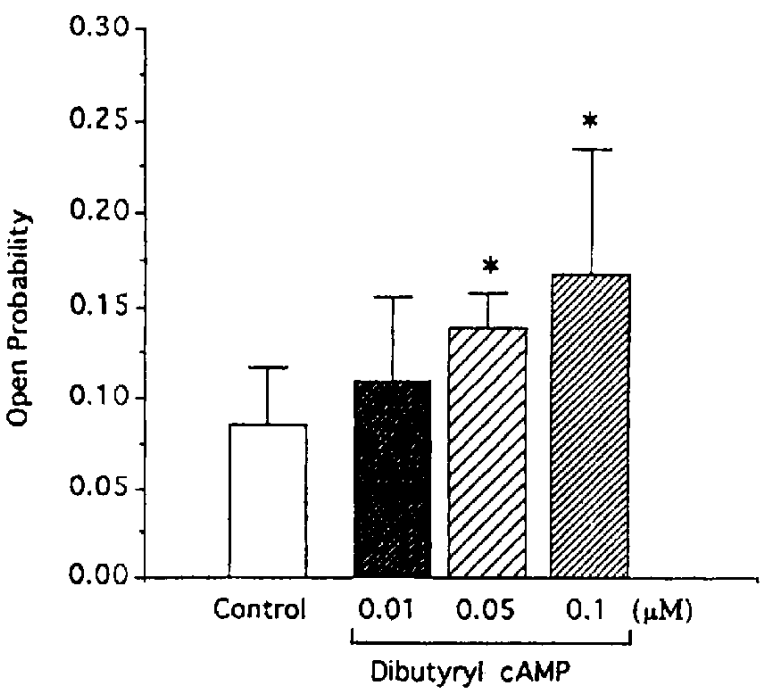

Fig. 3. Effects of dibutyryl cAMP on the open probability of inward currents elicited by a voltage step to $+20 \mathrm{mV}$ from a holding potential of $-40 \mathrm{mV}$. A: 5 consecutive cell-attached recordings at times indicated by arrows in B. B: Time course of dibutyryl cAMP-induced changes in open probability of inward currents by a voltage step every 10 sec. C: Maximal dibutyryl cAMP-induced changes in open probability of inward currents. Values are each the mean \pm S.E. from 5 experiments. ${ }^{*} P<0.05$, compared to the control.

\section{Current measurement}

The cells grown on coverslips were placed in an experimental chamber $(2 \mathrm{ml})$ on the stage of an inverted microscope (TMD; Nikon Kogaku, Tokyo). Heatpolished glass patch electrodes with a tip resistance of between 5 and 10 megohms were used. The seal resistance between the pipette tip and the cell membrane was more than 10 gigaohms. Experiments were conducted on cellattached membrane patches, as previously described (19).

Single-channel currents were recorded using a patchclamp amplifier (CEZ-2300; Nihon Kohden, Tokyo) and were stored on digital audio tape by a PMC datarecorder (D-180T; TEAC, Tokyo) for later analysis. Currents were low-pass filtered at $1-2 \mathrm{kHz}$. Actual records were 


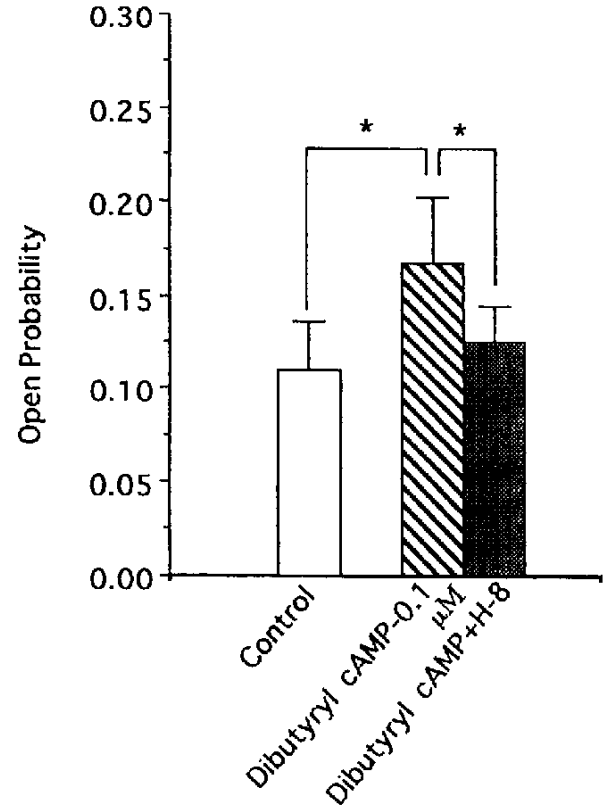

Fig. 4. Antagonistic effect of H-8 $(1 \mu \mathrm{M})$ on dibutyryl cAMP $(0.1$ $\mu \mathrm{M})$-induced enhancement of open probability of inward currents. Values are each the mean + S.E. from 6 experiments. ${ }^{*} \mathrm{P}<0.05$ (paired $t$-test).

recalled from the datarecorder at low speeds and were written out using a conventional thermowriting recorder (RTA-1100, Nihon Kohden). In the figures, the downward direction of the single channel currents indicate the inward current of the membrane. All experiments were performed at $30^{\circ} \mathrm{C}$.

\section{Solutions}

The pipette solution contained: $110 \mathrm{mM} \mathrm{BaCl}_{2}, 10 \mathrm{mM}$ tetraethylammoniun chloride, $10 \mathrm{mM} N^{\prime}$-2-hydroxyethylpiperazine- $N^{\prime}$-2-ethanesulphonic acid (HEPES) and was adjusted to $\mathrm{pH} 7.4$ with tris(hydroxymetyl)ethane- $\mathrm{OH}$. The bath solution contained: $140 \mathrm{mM}$ potassium gluconate, $10 \mathrm{mM}$ ethyleneglycol-bis- $N, N, N^{\prime}, N^{\prime}$-tetraacetic acid (EGTA), $1 \mathrm{mM} \mathrm{MgCl}$, and $10 \mathrm{mM}$ HEPES, and was adjusted to $\mathrm{pH} 7.4$ by $\mathrm{KOH}$. The high- $\mathrm{K}^{+}$concentration solution was used as a bath solution in order to produce a smooth muscle cell membrane potential of approximately $0 \mathrm{mV}$ except at the patch membrane. The solution in the chamber was rapidly exchanged by flushing with $5-10 \mathrm{ml}$ of the test solutions, and the over-flow was siphoned off by a water pump. Exchange of solution was carried out within $1 \mathrm{~min}$.

\section{Data analyses}

Histograms of open probability were calculated by a microcomputor (Signal processor 7T17; Nihondenki Sanei Instrument Co., Ltd., Tokyo). The probability of the channel being open (open probability) in each sweep was calculated from the total period of the channel being open divided by the duration $(400 \mathrm{msec}$ ) of the pulse. In general, when using patch pipettes, simultaneous opening of two or three unitary $\mathrm{Ba}^{2+}$ channels is usually observed. However, in the present experiments, patches that contained only one channel were used. Data are reported as the mean \pm S.E., and Student's $t$-test or the paired $t$-test was used for statistical analyses of the results.

\section{Drugs}

The medium used was Medium 199 (Nissui Chemicals, Tokyo), supplemented with fetal bovine serum (Kanto Reagents, Tokyo), streptomycin and penicillin (Meiji Pharmaceutical Chemicals, Tokyo). Nifedipine and Bay K 8644 were purchased from Research Biochemicals International (Natick, MA, USA), dibutyryl cAMP and 8-bromo-cGMP from Sigma (St. Louis, MO, USA), nitroglycerine from Nihonkayaku (Tokyo), forskolin from Wako (Osaka) and H-8 from Seikagaku Corporation (Tokyo). Nifedipine, Bay K 8644 and forskolin were dissolved in dimethylsulfoxide before addition to the bath. The final concentration of organic solvents was less than $1 \%$ and thus had no effect on the opening of the $\mathrm{Ca}^{2+}$ channel.

\section{RESULTS}

\section{Characterization of L-type $\mathrm{Ca}^{2+}$ channel currents}

Voltage-dependent $\mathrm{Ca}^{2+}$ channels in vascular smooth muscle consist of L- and T-types (1). Although both Land T-type channels are activated by steady holding potentials of $-70 \mathrm{mV}$, only L-type channels are activated by steady holding potentials of -40 to $-30 \mathrm{mV}$ (20). Figure 1A shows inward currents elicited by brief depolarizing steps to various potentials from a holding potential of $-40 \mathrm{mV}$. Figure $1 \mathrm{~B}$ shows the relationship between current and voltage (I-V). The voltage-dependent characteristics of inward currents were very similar to the L-type $\mathrm{Ca}^{2+}$ channel I-V curve found by Inoue et al. (21). Application of the L-type $\mathrm{Ca}^{2+}$ antagonist nifedipine (10 $\mu \mathrm{M})$ to the bathing solution abolished the open probability (Fig. 2A). Application of the L-type $\mathrm{Ca}^{2+}$ agonist Bay K $8644(5 \mu \mathrm{M})$ increased the open probability (Fig. 2B). These results indicate that the inward currents observed in the present study were carried almost exclusively by Ltype $\mathrm{Ca}^{2+}$ channels.

Effects of dibutyryl cAMP and forskolin on inward currents

Application of the membrane permeable dibutyryl cAMP $(0.01-0.1 \mu \mathrm{M})$ increased the open probability in a concentration-dependent manner (Fig. 3: A and B). Pre- 
A

a. Control
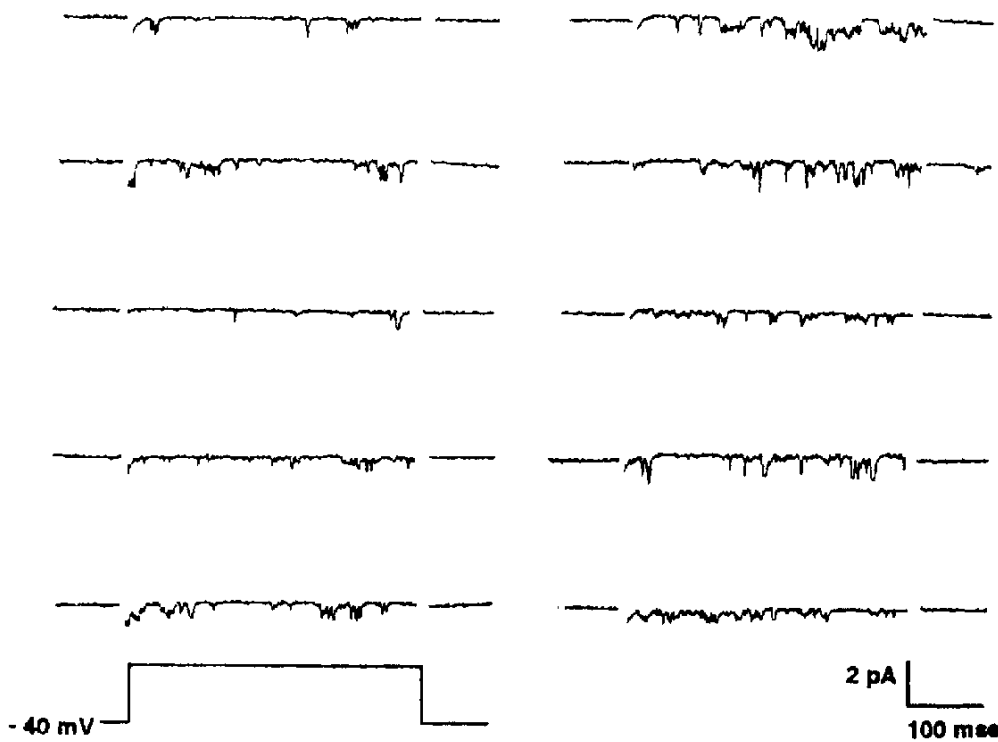

B

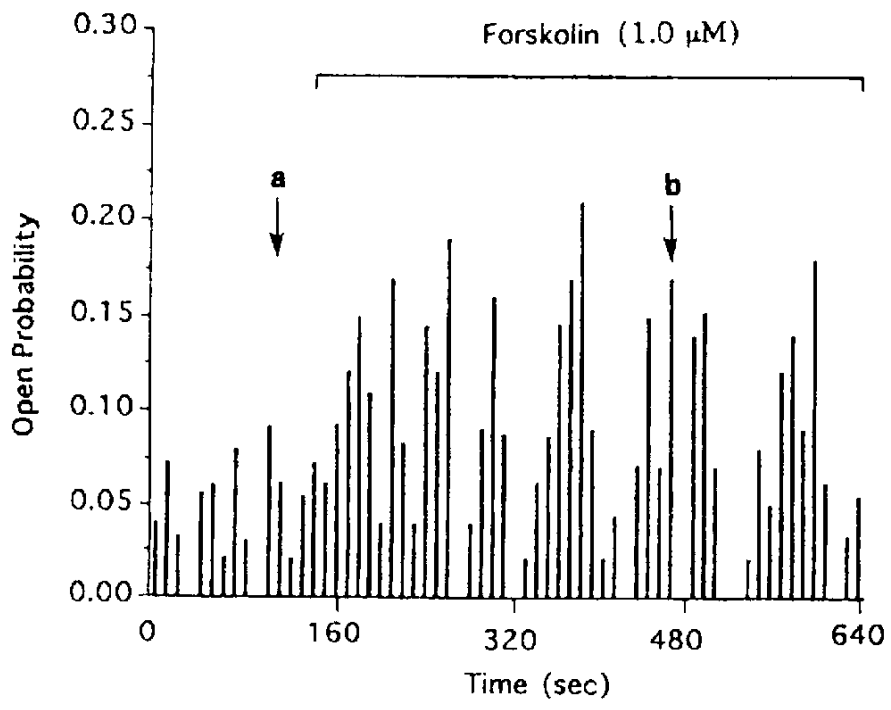

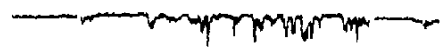

b. Forskolin
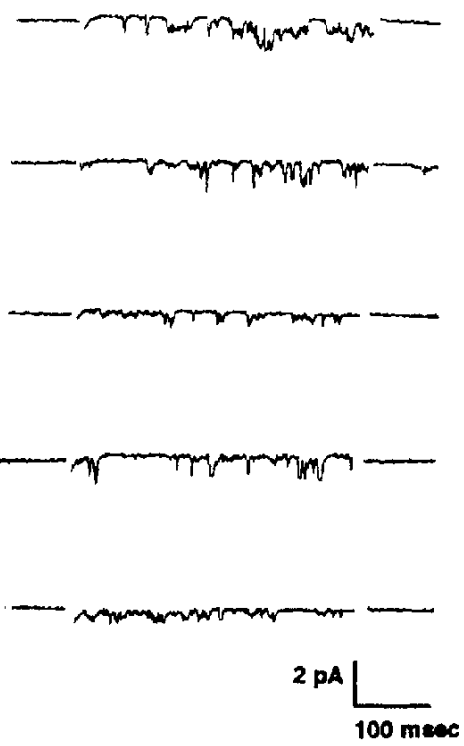

C

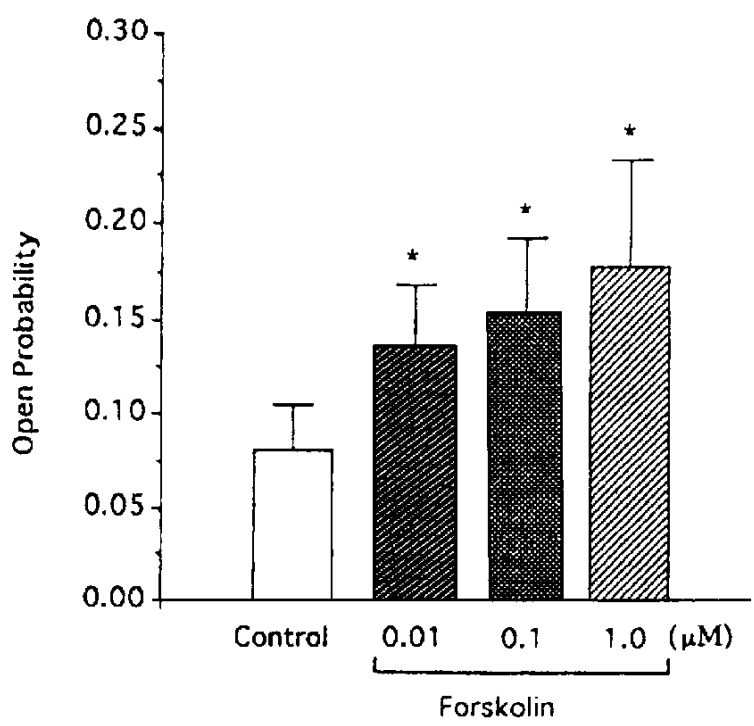

Fig. 5. Effects of forskolin on open probability of inward currents elicited by a voltage step to $+20 \mathrm{mV}$ from a holding potential of $-40 \mathrm{mV}$. A: 5 consecutive cell-attached recordings at times indicated by arrows in B. B: Time course of forskolin-induced changes in open probability of inward currents by a voltage step every 10 sec. C: Maximal forskolin-induced changes in open probability of inward currents. Values are each the mean \pm S.E. from 6 experiments. ${ }^{*} \mathrm{P}<0.05$, compared to the control.

application of the serine/threonine kinase inhibitor $\mathrm{H}-8$ $(1 \mu \mathrm{M})$ inhibited the enhancement of the open probability induced by dibutyryl cAMP $(0.1 \mu \mathrm{M})$ (Fig. 4). Application of forskolin $(0.01-1 \mu \mathrm{M})$, a direct activator of adenylate cyclase, also increased the open probability in a concentration-dependent manner (Fig. 5: A and B).
Effects of 8-bromo-cGMP and nitroglycerin on inward currents

Appliation of the membrane permeable 8-bromocGMP to the bath $(0.01-1 \mu \mathrm{M})$ produced a concentration-dependent inhibition of the open probability (Fig. 6A). Pre-application of the serine/threonine kinase inhi- 
A

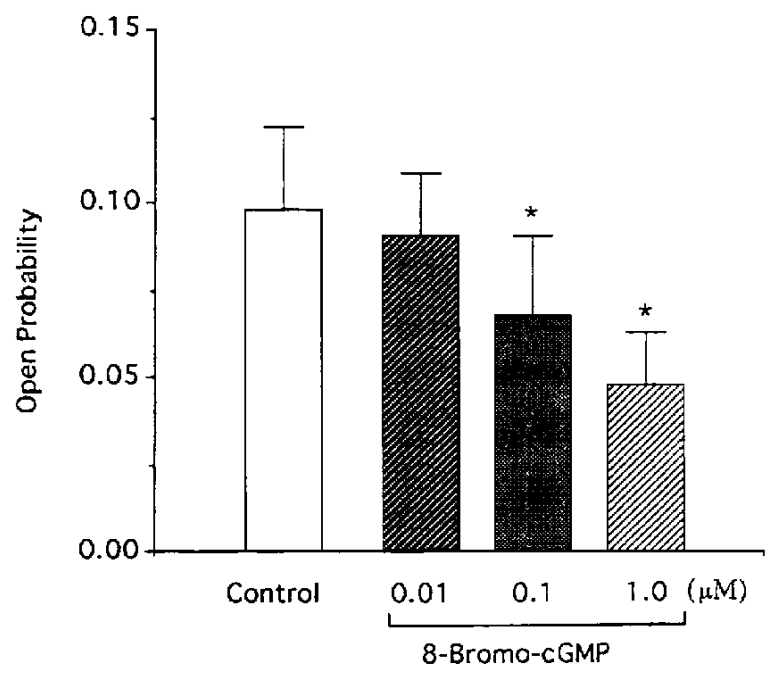

B

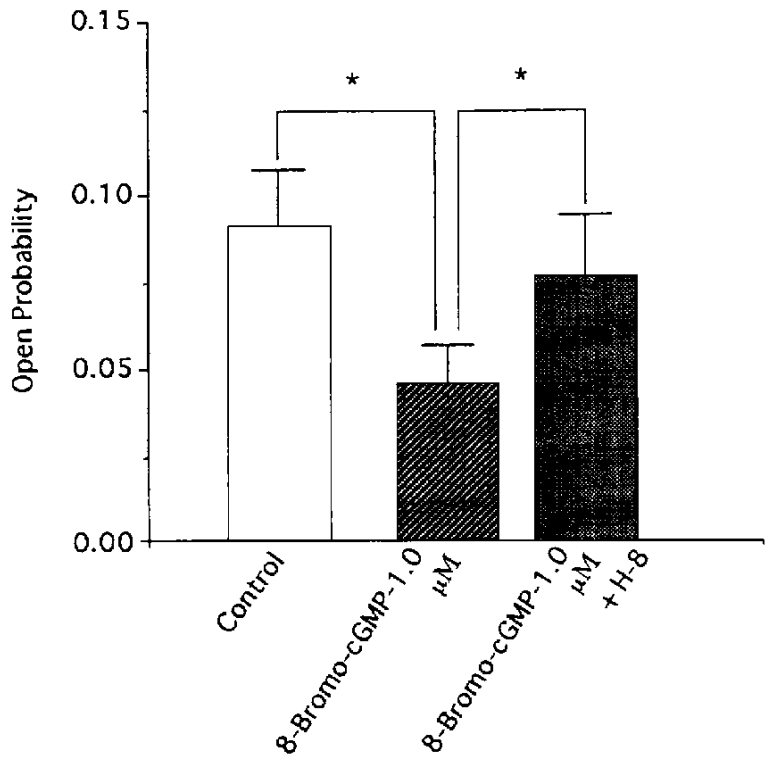

Fig. 6. Effects of 8-bromo-cGMP on open probability of inward currents elicited by a voltage step to $+20 \mathrm{mV}$ from a holding potential of $-40 \mathrm{mV}(\mathrm{A})$ and reversal of the 8-bromo-cGMP $(1 \mu \mathrm{M})$ effects by $\mathrm{H}-8(1 \mu \mathrm{M})(\mathrm{B})$. Values are each the mean $\pm \mathrm{S}$. E. from 6 experiments. ${ }^{*} \mathrm{P}<0.05$.

bitor $\mathrm{H}-8(1 \mu \mathrm{M})$ antagonized the inhibition of the open probability induced by 8-bromo-cGMP (1 $\mu \mathrm{M})$ (Fig. 6B). Application of the nitric oxide releaser nitroglycerin $(0.01-1 \mu \mathrm{M})$ to the bathing solution also inhibited the activity of the $\mathrm{Ca}^{2+}$ channel and decreased the open probability in a concentration-dependent manner (Fig. 7). $\mathrm{H}-8$ alone did not affect the activity of the $\mathrm{Ca}^{2+}$ channel $(n=5)$.

\section{DISCUSSION}

The effect of cAMP on vascular smooth muscle $\mathrm{Ca}^{2+}$ channels is controversial. In the present study, both the membrane permeable cAMP analogue dibutyryl cAMP and the direct adenlate cyclase activator forskolin produced an increase in the open probability of $\mathrm{Ba}^{2+}$ currents in rat mesenteric artery cells. The enhanced effect of dibutyryl cAMP was antagonized by the serine/threonine kinase inhibitor $\mathrm{H}-8$. These results suggest that a rise in intracellular cAMP levels leads to an enhancement of L-type $\mathrm{Ca}^{2+}$ channels. These results are in agreement with previous studies of procine coronary artery cells (9) and rabbit portal vein cells $(10)$.

We also found that the membrane permeable cGMP analogue 8-bromo-cGMP and the nitric oxide releaser nitroglycerin produced a decrease in inward currents in rat mesenteric artery cells. The inhibition effect of 8bromo-cGMP was antagonzed by the serine/threonine kinase inhibitor H-8. cGMP is widely accepted to be an important intracellular messenger in vascular smooth muscle cells and to mediate the effects of vasodilators such as endothelium-derived relaxing factor (nitric oxide) and nitrovasodilators $(14,15)$. Sodium nitroprusside has been shown to inhibit both high $\mathrm{K}^{+}$- and norepinephrine-induced ${ }^{45} \mathrm{Ca}$ uptake into tissue strips, suggesting cGMP-mediated supression of L-type $\mathrm{Ca}^{2+}$ channels (22, 23). These results suggest that a rise in intracellular cGMP levels may be due to inhibition of L-type $\mathrm{Ca}^{2+}$ channels. These observations are in agreement with a previous study of rabbit pulmonary artery cells using sodium nitroprusside, another nitric oxide releasing vasodilator (24).

In contrast with the results of the present study, in rabbit aorta, dibutyryl cAMP has been shown to inhibit L-type $\mathrm{Ca}^{2+}$ channel current (11). Isoprenaline has also been reported to suppress L-type $\mathrm{Ca}^{2+}$ channel inward current in rabbit ear artery cells (12). Ohya et al. observed that cAMP (but not ATP) had no effect on the voltagedependent $\mathrm{Ca}^{2+}$ current in rabbit jejunum smooth muscle cells (25). In addition, cAMP did not prevent the rundown phenomena of the $\mathrm{Ca}^{2+}$ channel current in single smooth muscle cells of guinea pig urinary bladder (26). Furthermore, internal perfusion of cAMP or dibutyryl cAMP had no effect on potentiation of the $\mathrm{Ca}^{2+}$ channel current by $\beta$-adrenoreceptor stimulation with isoprenaline (27). Despite the numerous reports suggesting a 
A

\section{a. Contral}

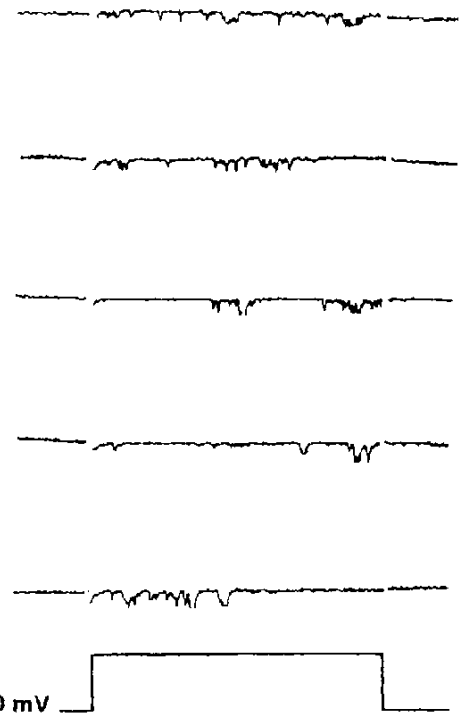

\section{b. Nitroglycerin}
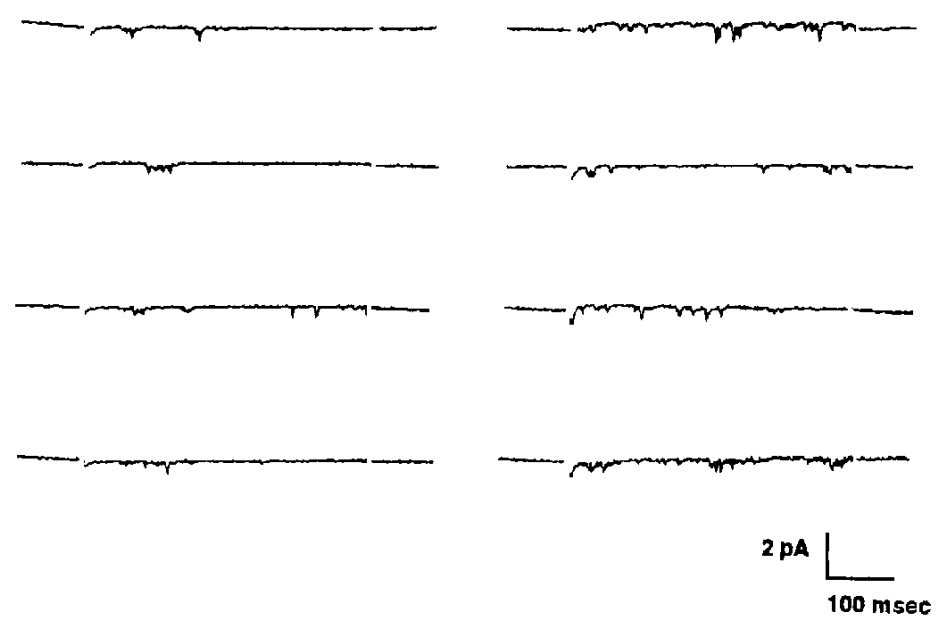

\section{c. Wash-out}
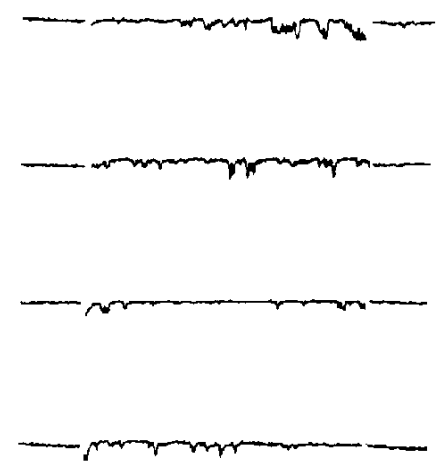

C

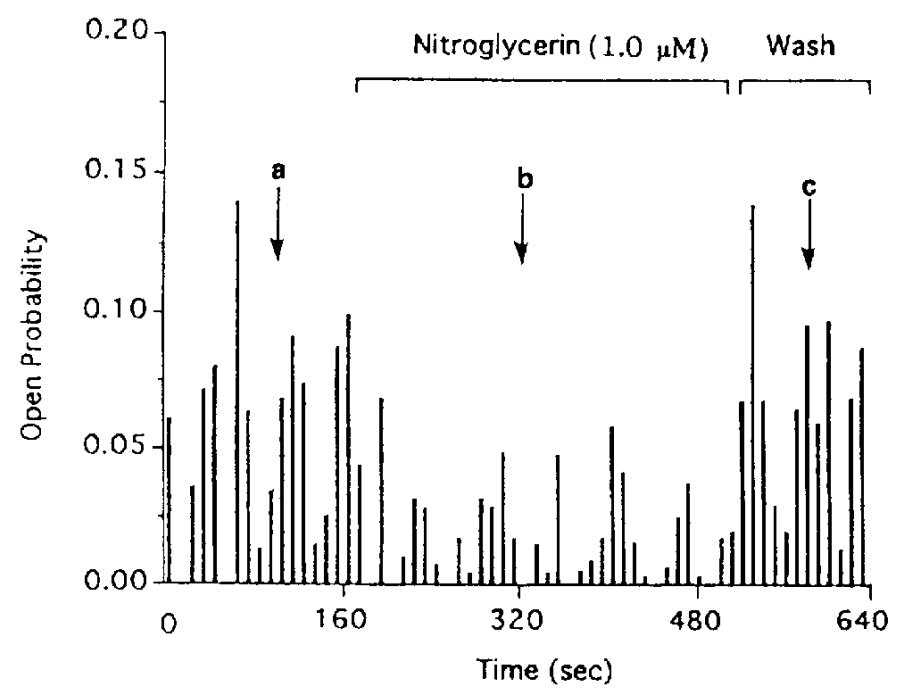

Fig. 7. Effects of nitroglycerin on open probability of inward currents elicited by a voltage step to $+20 \mathrm{mV}$ from a holding potential of $-40 \mathrm{mV}$. A: 5 consecutive cell-attached recordings at times indicated by arrows in B. B: Time course of nitroglycerin-induced changes in open probability of inward currents by voltage step every $10 \mathrm{sec}$. C: Maximal nitroglycerininduced changes in the open probability of inward currents. Values are each the mean \pm S.E. from 6 experiments. ${ }^{*} \mathbf{P}<0.05$, compared to the control.

regulatory role for cAMP in the voltage-dependent $\mathrm{Ca}^{2+}$ current, the action of cAMP has not been completely elucidated. Additionally, tissue differences may be partially responsible for these differences in cAMP-mediated modulation of smooth muscle $\mathrm{Ca}^{2+}$ channels.
In cardiac muscles, the phosphorylation of L-type $\mathrm{Ca}^{2+}$ channels by cAMP-dependent protein kinase is thought to be the most important in determining the force of contraction induced by $\beta$-adrenergic stimulation (6). However, in vascular smooth muscles, the possible phys- 
iological significance of cAMP-induced activation of $\mathrm{Ca}^{2+}$ channels is unclear because a rise in intracellular cAMP in vascular smooth muscles results in vasodilatation. On the other hand, cGMP-induced inhibition of L-type $\mathrm{Ca}^{2-}$ channels in vascular muscles may be involved in the expression of the blood vessel relaxing action of nitric oxide-mediating vasodilators such as atrial natriuretic peptide, nitroglycerin and acetylcholine $(15-17)$.

\section{Acknowledgments}

We gratefully acknowledge the helpful suggestions of Drs. Yoshihito Inoue and Kenji Kitamura (Department of Pharmacology, Faculty of Medicine, Kyushu University).

\section{REFERENCES}

1 Van Breemen C, Cauvin C, Johns A, Leitjen P and Yamamoto $\mathrm{H}$ : $\mathrm{Ca}^{2-}$ regulation of vascular smooth muscle. Fed Proc 45, 2746-2751 (1986)

2 Nelson MT, Patlak JB, Worley JF and Standen NB: Calcium channels, potassium channels, and voltage dependence of arterial smooth muscle tone. Am J Physiol 259, C3-C18 (1990)

3 Triggle DJ: Calcium channel drugs: Structure-function relations and selectivity of action. J Cardiovasc Pharmacol 18, Supp 10, S1-S6 (1991)

4 Triggle DJ: Calcium, calcium channels, and calcium antagonists. Drugs Dev 2, 3-13 (1993)

5 Reuter H: Calcium channel modulation by neurotransmitters, enzymes and drugs. Nature 301, 569-574 (1983)

6 Trautwein $W$ and Hescheler: Regulation of cardiac L-type calcium current by phosphorylation and G proteins. Annu Rev Physiol 52, 257-274 (1990)

7 Silver PJ, Walus $\mathbf{K}$ and DiSalvo: Adenosine-mediated relaxation and activation of cyclic AMP-dependent protein kinase in coronary arterial smooth muscle. J Pharmacol Exp Ther 228, $342-347$ (1984)

8 Bulbring $\mathbf{E}$ and Tomita T: Catecholamine action on smooth muscle. Pharmacol Rev 39, 49-96 (1987)

9 Fukumitsu $\mathrm{T}$, Hayashi $\mathrm{H}$, Tokuno $\mathrm{H}$ and Tomita $\mathrm{T}$ : Increase in calcium channel current by $\beta$-adrenoceptor agonists in single smooth muscle cells isolated from porcine coronary artery. $\mathrm{Br} \mathrm{J}$ Pharmacol 100, 593-599 (1990)

10 Ishikawa T, Hume JR and Keef KD: Regulation of $\mathrm{Ca}^{2+}$ channels by cAMP and cGMP in vascular smooth muscle cells. Circ Res 73, 1128-1137 (1993)

11 Bkaily G, Yamamoto T, Peyrow M, Sculptoreanu A, Jacques D and Sperelakis $\mathrm{N}$ : Macroscopic $\mathrm{Ca}^{2+}$ and $\mathrm{K}^{+}$currents in single heart and aortic cells. Mol Cell Biochem 80, 59-72 (1988)

12 Droogmans G, Declerck I and Casteels R: Effects of adrenergic agonists on $\mathrm{Ca}^{2+}$-channel currents in single vascular smooth muscle cells. Pflugers Arch 409, 7-12 (1987)
13 Ignarro $\mathrm{L} J$ and Kadovitz $\mathrm{PJ}$ : The pharmacological and physiological role of cyclic GMP in vascular smooth relaxation. Annu Rev Pharmacol Toxicol 25, 171-191 (1985)

14 Walter U: Physiological role of CGMP and cGMP-dependent protein kinase in the cardiovascular system. Rev Physiol Biochem Pharmacol 113, 42-88 (1989)

15 Lincoln TM: Cyclic GMP and mechanisms of vasodilation. Pharmacol Ther 41, 479-502 (1989)

16 Moncada S, Radomski MW and Palmer RM: Endotheliumderived relaxing factor, identification as nitric oxide and role in the control of vascular tone and platelet function. Biochem Pharmacol 37, 2495-2501 (1988)

17 Maragos CM, Morley D, Wink DA, Dunams TM, Saavedra JE, Hoffman A, Bove AA, Isaac L, Hrabie JA and Keefer LK: Complexes of NO with nucleophiles as agents for the controlled biological release of nitric oxide. Vasorelaxant effects. J Med Chem 34, 3242-3247 (1991)

18 Inoue $\mathrm{I}, \mathrm{Nakaya} \mathrm{Y}$, Nakaya $\mathrm{S}$ and Mori $\mathrm{H}$ : Extracellular $\mathrm{Ca}^{2+}$ activated $\mathrm{K}^{+}$channel in coronary artery smooth muscle cells and its role in vasodilation. FEBS Lett 255, 281-284 (1989)

19 Hamill OP, Marty A, Neher E, Sakmann B and Sigworth F: Improved patchclamp techniques for high resolution current recording from cells and cell free membrane patches. Pflugers Arch 391, 85-100 (1981)

20 Bean BP, Sturek M, Puga A and Hermsmeyer K: Calcium channels in muscle cells isolated from rat mesenteric arteries: Modulation by dihydropyridine drugs. Circ Res 59, 229-235 (1986)

21 Inoue $\mathrm{Y}$, Xiong $\mathrm{Z}$, Kitamura $\mathrm{K}$ and Kuriyama $\mathrm{H}$ : Modulation produced by nifedipine of the unitary Ba current of dispersed smooth muscle cells of the rabbit ileum. Pflugers Arch 414, $534-542$ (1989)

22 Kreye VAM, Baron GD, Luth JB and Schmidt-Gayk H: Mode of action of sodium nitroprusside on vascular smooth muscle. Naunyn Schmiedebergs Arch Pharmacol 288, 381-402 (1975)

23 Karaki $\mathrm{H}$, Nakagawa $\mathrm{H}$ and Urakawa N: Comparative effects of verapamil and sodium nitroprusside on contraction and ${ }^{45} \mathrm{Ca}$ uptake in the smooth muscle of rabbit aorta, rat aorta and guniea pig taenia coli. Br J Pharmacol 81, 393-400 (1984)

24 Clapp LH and Gurney AM: Modulation of calcium movements by nitroprusside in isolated vascular smooth muscle cells. Pflugers Arch 418, 462-470 (1991)

25 Ohya $\mathrm{Y}$, Kitajima $\mathrm{K}$ and Kuriyama $\mathrm{H}$ : Modulation of ionic currents in smooth muscle balls of the rabbit intestine by intracellularly perfused ATP and cyclic AMP. Pflugers Arch 408, 465-473 (1987)

26 Klockner U and Isenberg G: Calcium currents of cesium loaded isolated smooth muscle cells (uninary bladder of the guinea pig). Pflugers Arch 405, 340- 348 (1985)

27 Muraki K, Bolton TB, Imaizumi $Y$ and Watanabe M: Effect of isoprenaline on $\mathrm{Ca}^{2+}$ channel current in signal smooth muscle cells isolated from taenia of the guinea pig caecum. J Physiol (Lond) 471, 563-582 (1993) 